\title{
Model of Sustainable Community Participation in Homestay Program
}

\begin{abstract}
Aziz Amin
Yahaya Ibrahim

Universiti Sultan ZainalAbidin, Malaysia

wanazizmn@unisza.edu.my

\section{Doi:10.5901/mjss.2015.v6n3s2p539}

Abstract

Tourism is one of the important sectors contribute to the world economic growth according to the World Tourism Organization (UNTWO). The increase of international tourists arrival from 438 million in 1990 to 940 million in 2010 or 114.6 percentage show that the tourism sector has become a potential sector in providing a huge job market to the people. Referring to (UNWTO, 1998) the tourist arrivals are expected to increase 4.4 percent between years 2010 to year 2020. The aim of this study is to develop model of sustainable community participation in homestay program. A total of 306 respondents were selected using a stratified random sampling based on number of participants in the homestay program from several locations in Malaysia. All the data were analyzed using structural equation modeling (SEM). This study successfully developed fit model between community participation and sustainable development among the homestay participants. Finding from present study indicate that community participation in community-based tourism has influenced to the sustainable development among the homestay participant in the study area.
\end{abstract}

Keywords: community participation, community-based tourism, homestay, sustainable development

\section{Introduction}

Tourism has converted the essential provider to the world economic growth. The increasing of international tourists arrival from 438 million in 1990 to 940 million in 2010 or 114.6 percentage show that the tourism has a potential sector in providing a huge job market to the people. Referring to (UNWTO, 1998) the tourist arrivals are expected to increase 4.4 percent between years 2010 to year 2020. (RNCOS, 2009) conclude Malaysia is a popular tourism destination in the ASEAN because of the multicultural society, historical background and the beautiful of nature. The development of tourism sector in Malaysia begin in 1970 where the objectives are to increase income from money exchange, increase employability, encourage regional development and diversified economic base in order to increase revenue of the country. Currently the tourism sector turn out to be the main contributors to the economic growth in this country. The numbers of tourists are increased from 22 million in 2008 to 23.6 million in 2009. The figure increased in 2010 to 24.6 million. The numbers of tourist arrival are targeted 25 million by the year of 2015 (Tourism Malaysia, 2011) noted that the tourism sector will contribute 115 billion Ringgit Malaysia and provide two million employability to the country by the year 2015.

Realizing the potential of tourism sector, the government through Ministry of Tourism has formulated Tourism Transformation Plan 2020 to promote creativity and innovation in tourism industry to achieve the target 36 million tourist arrivals and revenue 168 billion ringgit Malaysia by 2020 (Tourism Malaysia, 2011). Government of Malaysia through the Ministry of Tourism and the Ministry of Rural Development has given special emphasis to the development of community rural tourism. The community based tourism (CBT) has become crucial in the tourism industry especially in Asian countries such as Thailand, Indonesia, Cambodia and also in others countries in Africa, United Kingdom, Australia and Carribbean. In Malaysia, a community based homestay is one the popular program in the CBT activities (Hamzah, 2009; Yusof et al., 2012). Based on the statistics from the Ministry of Tourism, the numbers of homestay participants in Malaysia has increased to 2984 in year 2010. The growing concerns of the homestay program are the sustainable revenue of the community participants is still low compared to the others types of accommodation. Whereas the participants involved in the program homestay are increased. The objective of this study is to develop structural model of sustainable community participation in homestay program in Malaysia.

\subsection{Community Based Tourism - Homestay Program}

Community based tourism (CBT) can be concludes as a person by some collective responsibilities and the ability to make 
collective decisions by representative bodies (Jamaludin et al., 2010). The first homestay program in Malaysia was started in Temerloh Pahang 1995 by Minister of Culture, Arts and Tourism. This program is under the $9^{\text {th }}$ Malaysia Plan (2006-2010). The main purpose of the government to set up this program is to rise income and to generate employability among the rural community through involving in the rural tourism industry. Community have their authority to resolve the development such as safeguards the environment and increase cultural awareness (Tsonis, 2009). The activities in the program were organized collectively by the local community. The visitors or tourists have a huges benefits from this program. The involvement of visitors in the activities which is planned by committee of the program will be able to expose them to recognize the culture of local communities and raise closer relation between them.

Homestay program concept in Malaysia is different from others countries. The guests have the opportunities to cooperate, share information, experience, values and life style of the host family as well as the local community. The two parties with the different cultural backgrounds would interact to each other in many activities together with their adopted families such as cooking, eating, and playing (Ibrahim, Y., \& Razzaq, A. R. A, 2009).

\section{Literature Review}

\subsection{Sustainable Tourism Development}

The World Tourism Organisation concluded that sustainable tourism development has become the essential tool in the economic growth and reduction of poverty in the certain areas. The involvement of several stakeholders and local communities in the decision making process is the most important strategy to postulate the sustainable tourism development (Augustyn, 1998). Wilson et al (2001) claim that the community participation and contribution is a critical factor for the successful rural tourism development. Crawley and Gillmor (2008) also takes into account all the different types of resources such as community participation in developing integrated rural tourism development. Sustainable tourism can be defined as "tourism which is developed and maintained of community or environment in such a manner that it remains viable over an infinite period and does not degrade or alter the environment (human or physical) in which it exists to such a degree that it prohibits the successful development and wellbeing of other activities and processes (Butler, 1991).

Sustainable development has comprehensively debated in the tourism sectors because of the development can postulate the chances to boost economic growth, safeguards environment and increase quality of life of local communities (Eagles, McCool, \& Haynes, 2002). The community based tourism has converted an essential tool for sustainable management (Sebele , 2010; Taylor, 1995).This finding support by Fallon \&Kriwoken (2003); Gursoy\& Rutherford (2004); Nicholas, Thapa \& Ko (2009) conclude that the development of sustainable tourism is challenging without assistance and involvement of the local residents. Theory exchange theory has been used to gauge the influence of community participation to the sustainable homestay program. Based on this theory, the community will assistance and contribute in the exchanges with visitors if they are benefit to the community. However if the activities are gain cost more than benefits, they are to dissent this activities or program development (Gursoy et al. 2002 ; Lee T H, 2013).

\subsection{Community participation}

Community participation is referring to the individual's willingness to engage and contribute in an activity in the decision making process, in accordance with the requirements (Til, 1984). In other words, community participation is to contribute to the establishment and development of the community based on existing resources (Stone, 1989). Community participation plays an important role in the development of sustainable tourism community. This is because the ability of communities to improve the positive factors in community-based tourism industry and reduces the negative factors that hinder the development community (Jamal \& Getz, 1995). Okazaki (2008) Selin \& Chavez (1995) noted that there are three levels of community participation consist of non-participation, degree of tokenism, and degrees of citizen power are used to assess various levels of involvement and participation in the community based tourism.Tosun (2006) conclude that by having the participatory approach, local community will gain the opportunities and benefits from the tourist which is taking place in their areas. Review by kayat (2007) concluded that community involvement in the homestay program is influenced by motivational factors. Therefore, to improve community participation in this program awareness and motivation courses should be provided to participants so that they can feel this homestay program can improve their living standards. In addition, local residents can also increase their knowledge by sharing the knowledge and experience through interaction with visitors (Brohman, 1996). 


\section{Methodology}

The proposed conceptual framework is based on the reviewed of literatures and the corresponding theoretical perspective as shown in figure 1. The variables were identified and the hypotesis have been developed which is shown in figure 1. The population for this study comprised of all the homestay participants derived from the Tourism Services Division, Ministry of Tourism, Malaysia. The number of participants in the Malaysian Homestay Program is 3,264 people. A total of 306 samples were selected using stratified random sampling and the data was processed and analyzed using the Statistical Package for Social Science (SPSS). Among the analysis is a reliability test, descriptive and inferential analysis.

Figure 1. Conceptual Framework

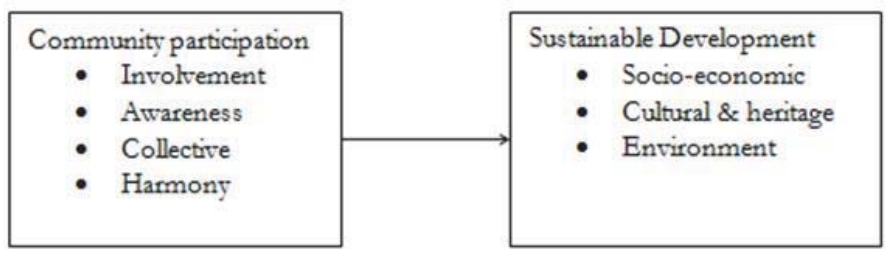

\section{Findings and Discussions}

\subsection{Demographic Profiles}

According to Table 1, of the total 306 respondents, 66 percent were female and 34 percent were male. The study also found that 60 percent of respondents were aged between 40 to 59 years and 80 percent were married. While education showed 30.1 percent is the basic level and education level SPM is 39.2 percent. In terms of work found 88.3 per cent of the working period under 10 years.

Table 1: Demographic Profiles

\begin{tabular}{|c|c|c|c|}
\hline Demographic Profile & Category & Frequency & Percentage \\
\hline Gender & $\begin{array}{c}\text { Male } \\
\text { Female }\end{array}$ & $\begin{array}{l}104 \\
202\end{array}$ & $\begin{array}{l}34.0 \\
66.0\end{array}$ \\
\hline Age & $\begin{array}{c}\text { Below } 20 \text { years } \\
20 \text { to } 29 \text { years } \\
30 \text { to } 39 \text { years } \\
40 \text { to } 49 \text { years } \\
50 \text { to } 59 \text { years } \\
60 \text { years and above }\end{array}$ & $\begin{array}{c}0 \\
10 \\
24 \\
85 \\
107 \\
80\end{array}$ & $\begin{array}{c}0.0 \\
3.3 \\
7.8 \\
27.8 \\
35.0 \\
26.1\end{array}$ \\
\hline Marriage Status & $\begin{array}{c}\text { Single } \\
\text { Married } \\
\text { Widower } \\
\end{array}$ & $\begin{array}{c}18 \\
242 \\
46 \\
\end{array}$ & $\begin{array}{c}5.9 \\
79.1 \\
15.0 \\
\end{array}$ \\
\hline Education & $\begin{array}{c}\text { Never go to School } \\
\text { Primary School } \\
\text { SRP/ PMR (completed form 3) } \\
\text { SPM (completed form 5) } \\
\text { STPM } \\
\text { Diploma } \\
\text { Degree }\end{array}$ & $\begin{array}{c}6 \\
92 \\
54 \\
120 \\
15 \\
13 \\
6\end{array}$ & $\begin{array}{c}2.0 \\
30.1 \\
17.6 \\
39.2 \\
4.9 \\
4.2 \\
2.0\end{array}$ \\
\hline Working Length/Period as participant of homestay & $\begin{array}{c}\text { Less than } 5 \text { years } \\
6 \text { to } 10 \text { years } \\
11 \text { to } 15 \text { years } \\
\text { 16years and above }\end{array}$ & $\begin{array}{c}182 \\
88 \\
32 \\
4\end{array}$ & $\begin{array}{c}59.5 \\
28.8 \\
10.5 \\
1.3\end{array}$ \\
\hline Monthly Income* & $\begin{array}{c}\text { RM300 and below } \\
\text { RM } 300 \text { to less than } 550 \\
\text { RM } 550 \text { and above }\end{array}$ & $\begin{array}{c}6 \\
19 \\
281\end{array}$ & $\begin{array}{c}2.0 \\
6.2 \\
91.8\end{array}$ \\
\hline
\end{tabular}




\subsection{Reliability Test and Data Normality}

As shown in the table 2, the mean value for each of dimension of community participation and sustainable development varies from 1.60 to 1.93. The standard deviation for these facets ranges from 0.40 to 0.45 . The alpha value for community participation is 0.873 . The alpha value for dependent variable that is sustainable development 0.920 . All these alpha values are higher than 0.6 meaning that the factors used in the study is suitable and can be accepted as a measurement (Sekaran, 2003). Furthermore, normality tests shows that the data is normally distributed since the value of skewness and kurtosis is below \pm 3 (Coakes and Steed, 2003)

Table 2. Descriptive and Correlation

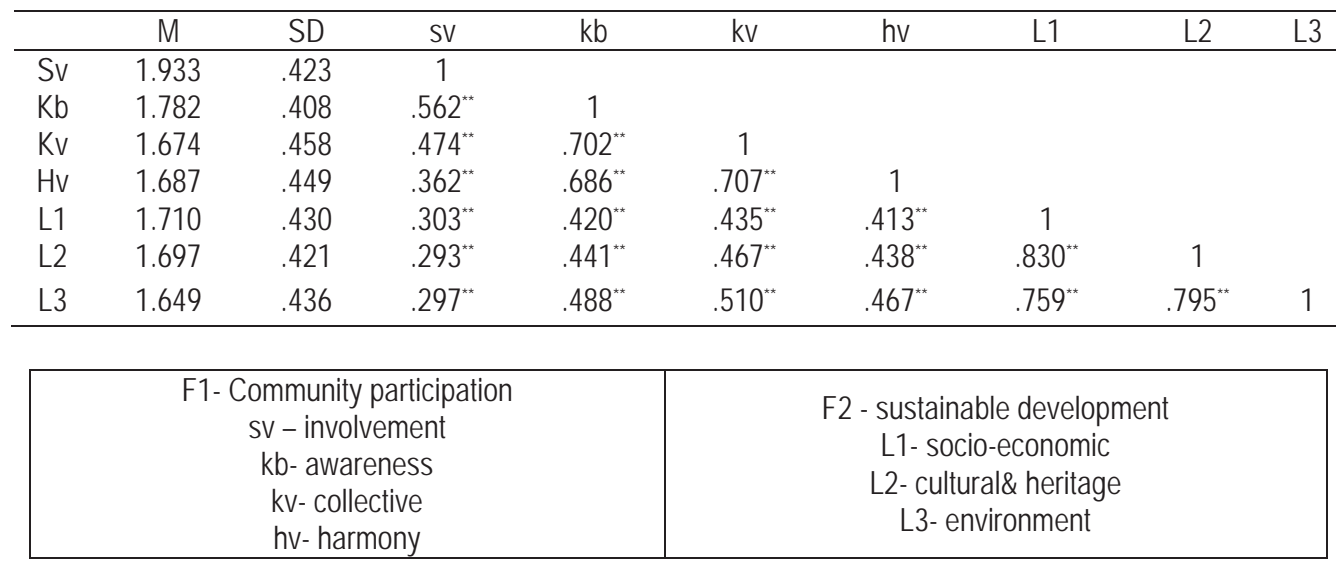

\subsection{The Assessment of Fitness for The Model}

Structural equation modeling technique was use to estimate multiple and interrelated dependence relationships and used to represent the unobserved concept in these relationships and account for the measurement error in the estimation process (Hair, 1998). In this study the unobserved exogenous variable is the community participationand unobserved endogenous variable is the sustainable development. Amos version 6 was used to measure the model fit. Several measures of goodness of fit were evaluated for the structural model: Chi-square/degree of freedom, Goodness of fit index (GFI), Adjusted goodness of fit index (AGFI), Normalized fit index(NFI), Comparative index (CFI) and Root mean square error of approximation (RMSEA).

\section{Table 3}

\begin{tabular}{ccc}
\hline Goodness of fit model Index & Recommended good fit value* & Proposed Model \\
\hline Chi-square & & 39.087 \\
Probability & $>.90$ & .000 \\
GFI & $>.90$ & .966 \\
NFI & $>.90$ & .972 \\
TLI & $>.90$ & .969 \\
CFI & $>.90$ & .981 \\
AGFI & $<.08$ & .926 \\
RMSEA & .081 \\
\hline
\end{tabular}

Hair, Anderson, Tathnam, Black (1998) and Arbuckle \&Wothke (1999)

The overall model fit is marginal with the values of GFI, NFI, TLI, CFI and RMSEA. The likelihood ratio chi-square value 39.087 with 310 degree of freedom is statistically at the 0.05 significant levels. It can be concluded that significant differences exist between the proposed model and the recommended model. The GFI value 0.966is at a marginally acceptable level, but the RMSEA has a value which falls inside the acceptable range of 0.08 . 


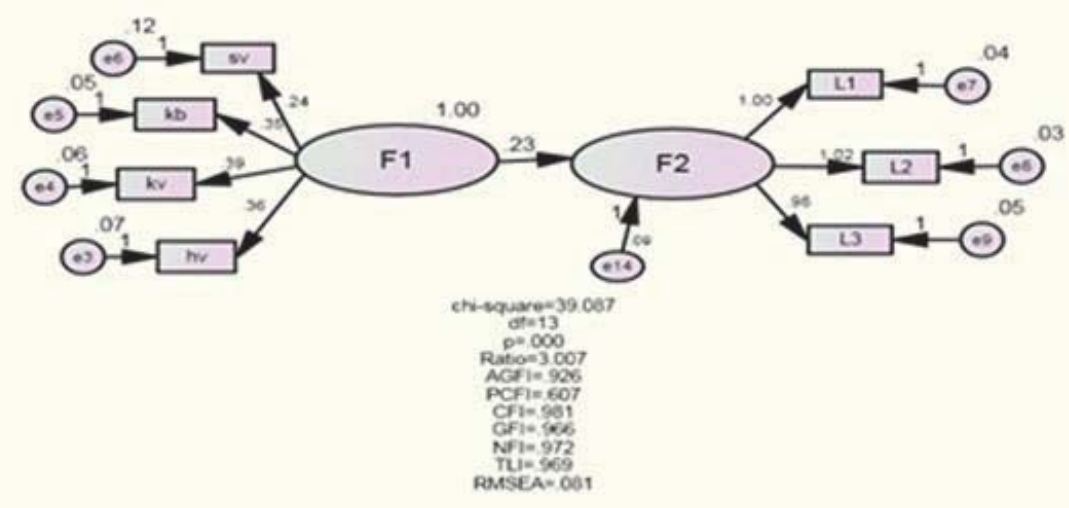

Table 4 shows the positive relationship between community participation and the sustainable development with coefficient value $.228, p<.001$. For the dimensions of community participation, it shows the significant contribution with the collective is the highest coefficient value .388 followers by harmony .361, awareness .346 and involvement .239 . These findings supports study by Lee (2012) conclude that the community attachment and community involvement are critical factors that affect the level of support for sustainable tourism development.

Table 4. Regression Weights

\begin{tabular}{|c|c|c|c|c|c|c|c|}
\hline & & & Estimate & S.E. & C.R. & P & Label \\
\hline F2 & $<--$ & F1 & .228 & .023 & 10.029 & 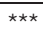 & par 3 \\
\hline $\mathrm{kb}$ & $<--$ & F1 & .346 & .020 & 17.614 & *** & par_1 \\
\hline L1 & $<--$ & F2 & 1.000 & & & & \\
\hline L3 & $<--$ & F2 & .983 & . 047 & 20.766 & 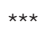 & par_2 \\
\hline sv & $<--$ & F1 & .239 & .023 & 10.243 & $\star \star \star *$ & par_4 \\
\hline hv & $<--$ & F1 & .361 & .022 & 16.262 & 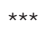 & par_5 \\
\hline kv & $<--$ & F1 & .388 & .022 & 17.558 & *** & par_6 \\
\hline L2 & $<--$ & F2 & 1.022 & .044 & 23.356 & $\star \star \star *$ & par 7 \\
\hline
\end{tabular}

\section{Conclusion}

The main objective of this study is to develop a model of sustainable community participation in the homestay program in Malaysia. This study has successful developed a fit model for the community participation and sustainable development in the homestay program. The results of the study have a similar to the previous studies (Aref F,2009;Stone L. S. \& Stone T. M. 2010; Ertuna B,2012) that suggested the community participation have influenced to the sustainable development in the community-based tourism. The development of the homestay program has contributed to the benefits of socio economic local community(Tsonis,2009). Logar (2009) pointed out that the community -based tourism has increased awareness among the local people about the cultural and heritage preservation. The biggest challenge in homestay program is to maintain the sustainable development among the participant. In order to sustain, the local government, local leader and the community have to play their roles in given supportive and participative in the development of the program. Findings from the study conclude that participation in the community-based tourism is influenced by the community members collective to participate. These collective could be explained by numerous factors such as their collective about handling activities among the participants, teamwork spirit, and their personality motivation. Therefore to maintain and enhance the sustainable of community based homestay program, the community project in their training module program should included the collective aspect, harmony, awareness and involvement among its members in order to educate them to be more competence and responsible in organizing the homestay program. 


\section{References}

Aref, F \& Gill, S. S. (2009). Rural Tourism Development through Rural Cooperatives.Nature and Science.Vo I7. No. 10, 68-73.

Augustyn, M. (1998). National Strategiesfor Rural Tourism Development and Sustainability: The Polish Experience. Journal of Sustainable Tourism. Vol. 6.No.2, 191-209.

Brohman, J. (1996). New Directions in Tourism for Third World Development. Annals of Tourism Research. Vol 23. 48-70.

Butler, R. W. (1991). Tourism, Environment, and Sustainable Development. Environmental Conservation.Vol.18. No.3, 201-209.

Cawley, M., \& Gillmor, D. A. (2008). Integrated Rural Tourism: Concepts and Practice. Annals of Tourism Research. Vol. 35. N0. 2, 316337.

Coakes, J. S., \& Steed, G. L. (2003).SPSS Analysis without Anguish Version 11.0 for Windows.John Wiley \& Sons Australia, Ltd.

Davidson, W. B., \& Cotter, P. R. (1991). The relationship between sense of community and subjective well-being: A first look. Journal of Community Psychology, 19, 246-253.

Dogan, H. (1989). Forms of adjustment: Socio-cultural impacts of tourism. Annals of Tourism Research, 16, 216-236.

Ertuna, B \&Kirbas, G. (2012) Local Community Involvement in Rural Tourism Development: The Case of Kastamonu, Turkey. PASOS.RevistadeTurismo y PatrimonioCultural.Vol 10 N0. 2, 17-24.

Eagles, P. F. J.,McCool, S. F.,\&Haynes, C. F. (2002). Sustainable Tourism in Protected Areas:Guidelines for Planning and management, Gland,Switzerland:InternationalUnion for The Conservation of Nature.

Fallon, L. D., \&Kriwoken, L. K., (2003). Community Involvement in Tourism Infrastructure: The Case of the Strahan Visitor Centre, Tasmania.Tourism Management. Vol. 24, 289-308

Field, A. (2003). Discovering statistics using SPSS for windows (1st ed.). London: Sage Publication.

Gursoy, D., Jurowski, C., \&Uysal, M. (2002). Resident Attitudes- A Structural Modeling Approach. Annals of Tourism Research. Vol. 29, 79-105.

Gursoy, D.,\&Rutherford, D. G. (2004). Host Attitudes Toward Tourism- An Improved Structural Model. Annals of Tourism Research.Vol.31,495-516

Hair, J. E., Anderson, R. E., Tathan, R. L., \& Black, W. C. (1998). Multivariate data analysis (5th ed.). New Jersey: Prentice-Hall International, Inc.

Hamzah, A (2009). The Growing Importance of Community Based Tourism in National Economies: A Global Perspective. International Seminar on Community Based Tourism: Learning From The Homestay Program in Malaysia.4-16 August 2009 ,Hotel UiTM, Shah Alam.

Ibrahim, Y., \& Razzaq, A. R. A. (2009). Homestay Program and Rural Community Development in Malaysia. International Workshop on Production Process of Tourism S and Interface among Local Residents, Foreign Tourists and Foreign Workers. Comparative Studies on Asian Countries.

Jamal, T \& Getz, D. (1995). Collaboration Theory and Community Tourism Planning Annals of Tourism Research. Vol 22, $183-202$.

Jamaludin, M; Othman, N \& Awang, A. B. (2010). Community Based Homestay Programme: A Personal Experience. Procedia Social and behavioral Sciences.42. 451-459

Kayat, K (2007). Exploring Factors Influencing Individual Participation in Community-Based Tourism: The case of kampung Relau Homestay Program, Malaysia. Asia Pasific Journal of Tourism Research.Vol. 7.Issue 2. 19-27.

Lee, T. H. (2012). Influence Analysis of Community Resident Support for Sustainable Tourism Development. Tourism Management.Vol. $34,37-46$

Logar, I. (2009). Sustainable Tourism Management in Crikvenica,Crotia: An Assessment of Policy Instruments, Tourism management. Vol 30.125-135

Nicholas, L., Thapa, B., Ko, Y. (2009).Residents' Perspectives of a World Heritage Site- The Pitons Management Area, St. Lucia.Annals of Tourism Research. Vol. 36,390-412

Okazaki, E. (2008). A Community-Based Tourism Model: Its Conception and use.Journal of Sustainable Tourism. Vol 16.No 5, 511-529.

RNCOS. (2009). Tourism industry, Malaysian tourism industry forecast to 2012: Industry research report. Delhi, RNCOS E-Services Pvt. Ltd.

Sekaran, U. (2003). Research Method For Business: A Skill Building Approach (4th ed.). John Willey \& Sons, Inc. New York.

Selin, S. \&Chavez,D.(1995). Developing a Collaborative Model for Environmental Planning and Management .Environmental Management.Vol.9, 189-195.

Stone, L. (1989). Cultural Cross-Roads of Community Participation in Development

Stone, L. S. \& Stone, T. M. (2010). Community-Based Tourism Enterprises: Challenges and Prospects for Community Participation; Khama Rhino Sanctuary Trust,Botswana. Journal of Sustainable Tourism. Vol. 19, No. 1 97-114.

Taylor, G. (1995). The Community Approach: Does it Really Work? Tourism Management.Vol 16.,487-489.

Til, V. J. (1984).Citizen Participation in The Future.Policy Studies review.Vol. 3, No. 2,311-322.

Tourism Malaysia. (2011). Tourism Today. Quarterly Issue. Kuala Lumpur. Tourism Malaysia and Ministry of Tourism Malaysia.

Tosun, C. (2006). Expected Nature of Community Participation in Tourism Development.Tourism Management. Vol. 27, $493-504$.

Tsonis, J. L (2009). The Promotion of Community-Based Tourism as a Product, International Seminar on Community Based Tourism: Learning from the Homestay Programme in Malaysia, Towards Developing a Sustainable Community Based Tourism: Issues Impacts \& Opportunities, 4-16 August 2009,Hotel UiTM, Shah Alam Selangor Malaysia.

Wilson, S., Fesenmaier, D. R., Fesenmaier, J and Van Es, J. C. (2001).Factors for Success in Rural Tourism development.Journal of 
Travel reseaech. Vol.40, 132-138

World Tourism Organization (UNWTO). (1998). Executive summary. Tourism 2010 Vision: A new forecast from the World Tourism Organization. World Tourism Organization, Madrid.

Yahaya Ibrahim \& Abdul Rasid Abdul Razzaq (2009). Homestay Program and Rural Community Development in Malaysia. International Workshop on Production Process of Tourism S and Interface among Local Residents, Foreign Tourists and Foreign Workers. Comparative Studies on

Yusof, Y., Ibrahim, Y., Muda, M. S., \& Amin, W. A. A. W. M. (2012). Community based tourism and quality of life. Review of Integrative Business and Economics Research, 1(1).Asian Countries. 